\title{
Impact of Atmospheric Parameters on Power Generation of Wind Turbine
}

\author{
Ravindra B. Sholapurkar ${ }^{1}$, Yogesh S. Mahajan ${ }^{2}$ \\ ${ }^{1}$ Department of Chemical Engineering, DR. Babasaheb Ambedkar Technological University, Lonere, Tal Mangaon, Dist. Raigad, \\ Maharashtra, India \\ ${ }^{2}$ DR. Babasaheb Ambedkar Technological University, Lonere, Tal Mangaon, Dist. Raigad, Maharashtra, India
}

\section{Email address:}

rbsat68@gmail.com (R. B. Sholapurkar), yogesh_mahajan66@yahoo.com (Y. S. Mahajan), ysmahajan@dbatu.ac.in (Y.S. Mahajan)

${ }^{*}$ Corresponding author

\section{To cite this article:}

Ravindra B. Sholapurkar, Yogesh S. Mahajan. Impact of Atmospheric Parameters on Power Generation of Wind Turbine. American Journal of Energy Engineering. Vol. 4, No. 2, 2016, pp. 17-25. doi: 10.11648/j.ajee.20160402.12

Received: April 27, 2016; Accepted: May 13, 2016; Published: May 30, 2016

\begin{abstract}
Economic growth of any country depends on access to reliable energy. Wind energy is fast gaining importance among non-conventional sources, which is a function of parameters like topography of the terrain, weather conditions etc. The present work explores the potential of a $225 \mathrm{MW}$ turbine located in a mountainous site in Maharashtra, India. Values of wind velocity, air temperature, density and power generation were recorded for one complete year. Analysis was done using power curves. The results show that the energy output of wind turbine is based on power curves of a specific site. The conceptual features such as energy per rated power, efficiency of wind turbine and average energy per hour are calculated. It is useful for the investor to access the wind turbine pay-back period and adopt of new optimizing technique.
\end{abstract}

Keywords: Wind Energy, Atmospheric Parameters, Wind Power Generation

\section{Introduction}

Owing to the exponential escalation of world population, the requirement for energy is increasing at a huge rate. The exhaustion of fossil fuels as well as the upcoming realization of the environmental degradation has given precedence to the use of conventional and renewable alternative energy sources like solar, wind and solar-hydrogen energy [1]. In recent years, the fast development in wind energy technology has made it a promising alternative to the conventional energy system. Wind energy systems have made a noteworthy contribution to everyday life in developing countries [2,3]. As the developing countries are preparing to meet their needs during the $21^{\text {st }}$ century, they are confronting many challenges, in the use and deployment of renewable energy sources.

To suffice the world's electricity needs, the wind energy potential is vast [4]. Almost every country has sites with regular wind speeds of more than $5 \mathrm{~m} / \mathrm{s}$ measured at a height of $10 \mathrm{~m}$, which are adequate for development $[5,6]$. The production of wind energy depends on the geographic and environmental conditions of the wind turbine location.
Furthermore, wind data having real statistical significance, i.e. data obtained over long periods is a requisite for the assessment of generation of specific plants and the relative technical-economic considerations [7]. Such data is only scarcely available in the literature $[8,9]$. Through systematic recordings of wind speed and direction is a potential site for the development of wind energy. [10]. Wind surveys and installations have up to now been concerned with on-land sites [11]. Better wind velocity will lead to more amount of wind power generation. The offshore sites and shallow water sites are better for windmill installation but maintenance and installation [12].

The low energy concentration of wind, its variations and unsystematic availability over time, collide with the needs of electricity production [13]. Above all, the low energy concentration in wind signifies that, a big number of wind turbines need to be used where a wind plant of major power is to be built, which should be huge in size taking into account of the installed generating capacity [14]. However, as an additional source of electricity under suitable conditions, wind can still be put to a good use [15], chiefly 
since it is easily accessible, with no emissions and since it allows additional diversification of energy sources. World watch Institute (USA) has reported that wind power plants are liable to provide more employment opportunities per Terawatt-hour produced per year than any other energy technology used by the electricity utilities [16]. Also noteworthy is the fact that, in growth with other kinds of generating plants, the so-called "energy payback time" is less for wind energy, as it differs from a few months to one year at most, as it relies on the size of the wind turbine. While a machine has functioned for this period, it has produced enough energy to provide for another wind turbine similar to it [17]. Energy is the chief measure of all kinds of work by human beings, nature and all that happens in the world is the flow of energy in one to the other form.

\section{Importance of Wind Turbine as Alternate Source of Energy}

Wind gets its movement as a result of its energy. A device competent of slowing down the mass of moving air can haul out part of the energy and thus this energy can be switched into useful work [18]. Following aspects direct the output of wind energy converter: the wind speed, cross-section of the wind swept by rotor, conversion efficiency of rotor and generator transmission system. Hypothetically, it is possible to get $100 \%$ efficiency by arresting and averting the channel of air through the rotor. But in reality, a rotor is proficient to slow down the air column merely to one third of its free velocity or so [19]. A competent wind generator is capable to switch maximum up to $60 \%$ of the accessible energy in wind into mechanical energy. Additionally, the whole efficiency of the power generation can go down to, say, $35 \%$ owing to the losses incurred in the generator or pump [20,21].

\section{Wind as Secondary Source Derived from Sun}

The sun's non-uniform heating of the earth's surface results in the circulation of air in the atmosphere. As the temperature of the earth's surface heats up, the air present over the earth's surface will become light in weight and expand; it is compelled upwards by cool, denser air which blows in from surrounding areas causing the wind to flow. The strength of wind and the nature of wind depend upon the nature of the land; the quantity of cloud over and the angle of the sun in the sky. Generally, the air above the earth's surface tends to heat up more during the day time than air over the water surface. In coastal areas, during the day time, earth surface will become hot swiftly than water surface. In the nighttime however, this course of action is reversed, and cool air flows off shore [22].

As the solar input keeps on differing, the change and course of these terrestrial winds alter with the seasons. The terrestrial winds are caused when the breezy surface air sweeps downward from the poles powering the warm air over the tropics to mount [23]. However, the course of these huge air movements affected by the revolving of the earth and the net outcome is a large counter-clockwise movement of air around low-pressure regions in the northern hemisphere and clockwise movement in the southern hemisphere [24]. It is known that the regular wind speeds are superior in hilly and coastal areas than they are in the inlands. The winds also have a tendency to blow more consistently and with superior potency above the surface of the water where there is a less surface drag. However the wind patterns are remarkably constant despite the alternating nature of the wind [25]. Wind velocity amplifies in magnitude with elevation. It has been shown that at a height of ten meters, velocity is found to be $20-25 \%$ greater than at the surface. At an elevation of $60 \mathrm{~m}$, it may be $30-60 \%$ higher on account of the reduction in the drag effect of the earth's surface [26].

\section{Wind Power}

Wind energy is possessed by the movement of air. The moving air is cut by a device like propeller and the kinetic energy is converted into useful work, the process being known as harnessing of wind energy [27].

There are three factors on which the wind energy depends:

- The wind speed

- The cross-section of wind swept by rotor

- The overall conversion efficiency of the rotor, transmission system and generator or pump

German physicist Albert Betz concluded in1919 that no wind turbine can convert more than $16 / 27$ (59.3\%) of the kinetic energy of the wind into mechanical energy turning a rotor. To this day, this is known as the Betz Limit or Betz' Law. The theoretical maximum power efficiency of any design of wind turbine is 0.59 (i.e. no more than $59 \%$ of the energy carried by the wind can be extracted by a wind turbine). This is called the "power coefficient" and is defined as: $C p \max =0.59$ [15].

$$
\mathrm{p}=\frac{1}{2} \rho \mathrm{Av}^{3} C_{p}
$$

Where $\mathrm{p}=$ power generation, $\rho=$ air density, $\mathrm{A}=\mathrm{swept}$ area, $\mathrm{v}=$ wind velocity and

$C_{p}=$ Power co-efficient

\section{Case Study}

In this work we have selected a site with wide variation of wind speed (from $5-13 \mathrm{~m} / \mathrm{s}$ ) and the site itself is windy. The location is at Dhebewadi, Taluka Karad, District Satara, in the state of Maharashtra, India, which is at a mean sea level (MSL) of $1012 \mathrm{~m}$. The average rainfall during monsoon (June - September) is $36 \mathrm{~mm}$. The average percentage of humidity is $60 \%$. There are several wind turbines at this place by private players viz. VESTAS, SUZULON, TATA POWER etc. The data obtained for one particular turbine run by VESTAS turbine is used in this work. The turbine details are: Rotor diameter: $82 \mathrm{~m}$, Effective diameter of blade: $78 \mathrm{~m}$, 
Gearbox rated power: $1800 \mathrm{KW}$, Gearbox Ratio: 1:84.3, Rated Power: $1650 \mathrm{KW}$, Speed: $1200 \mathrm{rpm}$, Apparent Power: 1808 KVA, Rated current: 1740 A.

\section{Methodology}

The data pertaining to various parameters and power generated for the particular wind turbine was noted for one complete year (January - December 2014). Parameters like average temperature, average velocity and average density were calculated along with number of hours, the turbine worked and the average power generation in the given month was calculated from year - long data. From this the average energy, capacity of the plant, energy per swept area and energy per rated power were also calculated and are shown in (Table 1). Sample calculations for the month of January are shown below in the equation 2 to equation7. Also since power generation depends on factors like wind speed, air temperature and air density, so effect of these on power generation are plotted Fig. $(1-6)$. Also the overall effect of various parameters on power generation is as shown in Fig. (7). the turbines rated or nominal power is $1650 \mathrm{KW}$. The complete analysis of the VESTAS wind turbine for the year 2014 is made with the help of equation from 8 to equation 13. By this we can come know that, weather the present turbine is working efficiently and many more important calculations like energy per rated power and energy per swept area.

\subsection{Monthly Calculation for Example January 2014}

$1 \quad$ Swept Area $=\frac{\pi d^{2}}{4}=\frac{\pi}{4}(82)^{2}=5281 \mathrm{~m}$

2 Average hour turbine worked $=\frac{\text { No.of hours turbine } \text { worked in month }}{\text { No.of days in month }}=\frac{456.5}{31}=14.72$ hours $/$ day

Average Energy Kw/hr. $=\frac{\text { Average Power generation }}{\text { Average hour turbine } \text { worked }}=\frac{4697.02}{14.72}=319.09 \mathrm{KW} / \mathrm{hours}$

Energy per swept area $=\frac{\text { Average Power generation }}{\text { Total Swept Area }}=\frac{4697.02}{5281}=0.89 \mathrm{Kw} / \mathrm{m}^{2}$

Energy per rated (nominal) Power $=\frac{\text { Average Power generation }}{\text { Rated Power }}=\frac{4697.02}{1650}=2.84 \mathrm{Kwh} / \mathrm{Kw}$

6 Capacity factor or efficiency $=\frac{\text { Average Power generation }}{\text { Rated Power }} \times 100=\frac{4697.02}{1650 \times 24 \times 31} \times 100=0.38$

\subsection{Detailed Analysis of the Turbine for the Year 2014}

$7 \quad$ Average turbine worked $=\frac{\text { Total No.of hours turbine } \text { worked in year }}{\text { Total No.of days } \text { in year }}=\frac{7118.7}{365}=19.5$ hours $/$ day

Average Energy of turbine $\mathrm{Kw} / \mathrm{hr}=\frac{\text { Average Power generation in year }}{\text { Average hour turbine worked }}$

$=\frac{1,39,989}{365}=383.53 \mathrm{Kw} /$ day $($ generated per day)

$9 \quad$ Energy per swept Area $=\frac{\text { Power Production Per Year }}{\text { Swept Area }}=\frac{1,39,989}{5281}=26.5 \mathrm{~K} / \mathrm{m}^{2}$

Energy per rated Power $=\frac{\text { Production Per year }}{\text { Rated Power }}=\frac{1,39,989}{1650}=84.84 \mathrm{Kwh} / \mathrm{Kw}$

Capacity Factor $=\frac{\text { Production Per year }}{\text { Rated Power }}=\frac{1,39,989}{1650 \times 24 \times 365} \times 100=0.97 \%$

Tip Speed $=\frac{2 \pi n r}{60}=\frac{2 \pi \times 14 \times 41}{60}=60.10 \mathrm{~m} / \mathrm{s}$, When $\mathrm{n}=14 \mathrm{rpm}$, Radius $\mathrm{r}=41 \mathrm{~m}$

Table 1. Monthly average temperature, average velocity and average density for year 2014.

\begin{tabular}{|c|c|c|c|c|c|c|}
\hline Sr No & Month & $\begin{array}{l}\text { Average } \\
\text { Temperature C }\end{array}$ & $\begin{array}{l}\text { Average } \\
\text { Velocity m/s }\end{array}$ & $\begin{array}{l}\text { Average Air } \\
\text { density } \mathrm{Kg} / \mathrm{m}^{3}\end{array}$ & $\begin{array}{l}\text { No of hours turbine } \\
\text { worked in month }\end{array}$ & $\begin{array}{l}\text { Average Power } \\
\text { generation Kw }\end{array}$ \\
\hline 1 & January & 23.7 & 5.4 & 1.20 & 456.5 & 4697.02 \\
\hline 2 & February & 30.8 & 5.2 & 1.16 & 653.9 & 7131.2 \\
\hline 3 & March & 34.5 & 5.2 & 1.14 & 727 & 10189.9 \\
\hline 4 & April & 36.7 & 4.83 & 1.14 & 701 & 10906.7 \\
\hline 5 & May & 38.4 & 8.6 & 1.14 & 718.3 & 12093.8 \\
\hline 6 & June & 29.0 & 11.7 & 1.16 & 693.3 & 22610.2 \\
\hline 8 & August & 25.1 & 11.48 & 1.18 & 713.2 & 28537.3 \\
\hline 9 & September & 24.6 & 4.34 & 1.18 & 357.1 & 4026.53 \\
\hline 10 & October & 25.9 & 6.62 & 1.18 & 427.7 & 2017 \\
\hline 11 & November & 26.1 & 6.8 & 1.18 & 482 & 2822.25 \\
\hline \multirow[t]{2}{*}{12} & December & 22.3 & 5.66 & 1.20 & 485.7 & 2766 \\
\hline & & & & & 7118.7 & $1,39,989$ \\
\hline
\end{tabular}


Table 1. Contuine.

\begin{tabular}{lllllll}
\hline Sr No & Month & $\begin{array}{l}\text { Average hour turbine } \\
\text { worked per day (hours) }\end{array}$ & $\begin{array}{l}\text { Average energy } \\
\text { kw/hr }\end{array}$ & $\begin{array}{l}\text { Energy per } \\
\text { swept area }\end{array}$ & $\begin{array}{l}\text { Energy per } \\
\text { rated power }\end{array}$ & Capacity of plant \\
\hline 1 & January & 14.72 & 319.09 & 0.89 & 2.84 & 0.38 \\
2 & February & 22.54 & 316.38 & 1.35 & 4.32 & 0.64 \\
3 & March & 23.45 & 434.54 & 1.93 & 6.17 & 0.83 \\
4 & April & 23.36 & 466.89 & 2.07 & 6.61 & 0.91 \\
5 & May & 23.17 & 521.96 & 2.29 & 7.33 & 0.98 \\
6 & June & 23.11 & 978.37 & 4.28 & 13.70 & 0.90 \\
7 & July & 22.67 & 1419.99 & 6.09 & 19.50 & 2.62 \\
8 & August & 23.00 & 1240.75 & 5.41 & 17.29 & 2.32 \\
9 & September & 11.90 & 338.36 & 0.76 & 0.20 & 0.33 \\
10 & October & 13.79 & 146.26 & 0.38 & 0.9 & 0.16 \\
11 & November & 16.06 & 175.73 & 0.53 & 1.71 & 0.24 \\
12 & December & 15.66 & 176.63 & 0.52 & 1.68 & 0.23 \\
\hline
\end{tabular}
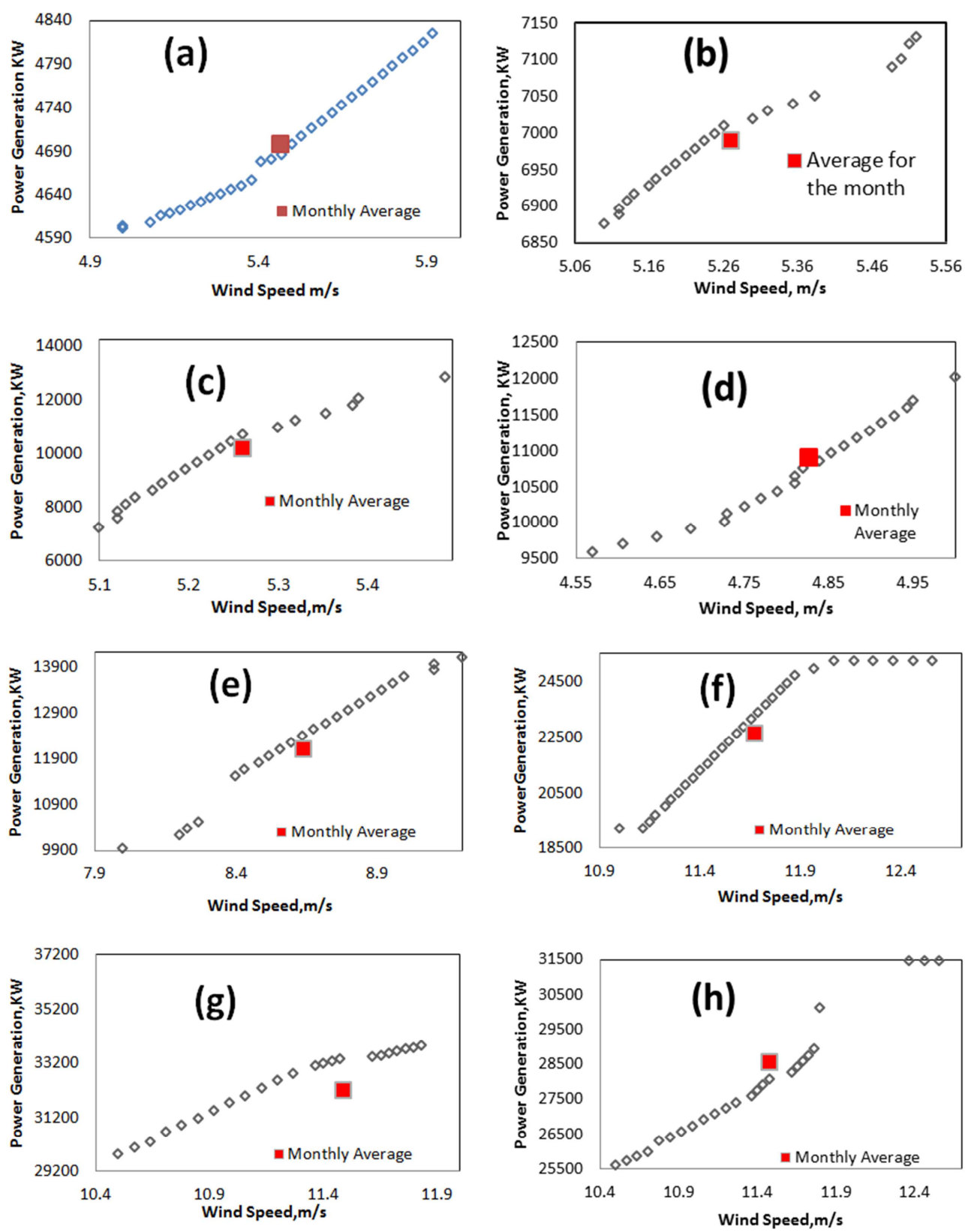

Fig. 1. Effect of wind speed on power generation for (a) January, (b) February, (c) March, (d) April, (e) May, (f) June, (g) July and (h) August 2014. 

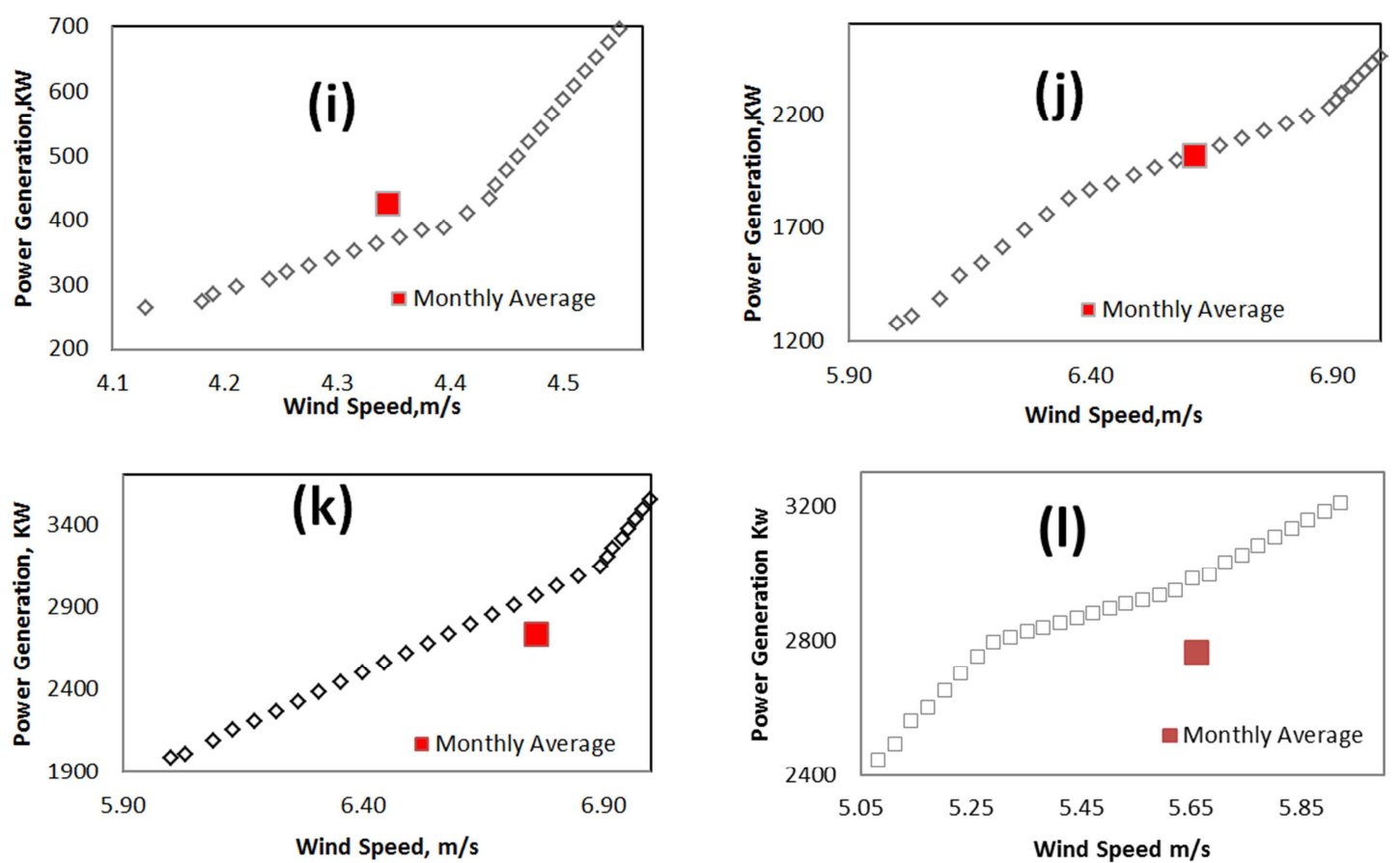

Fig. 2. Effect of wind speed on power generation for (i) September, (j) October, (k) November and (l) December 2014.
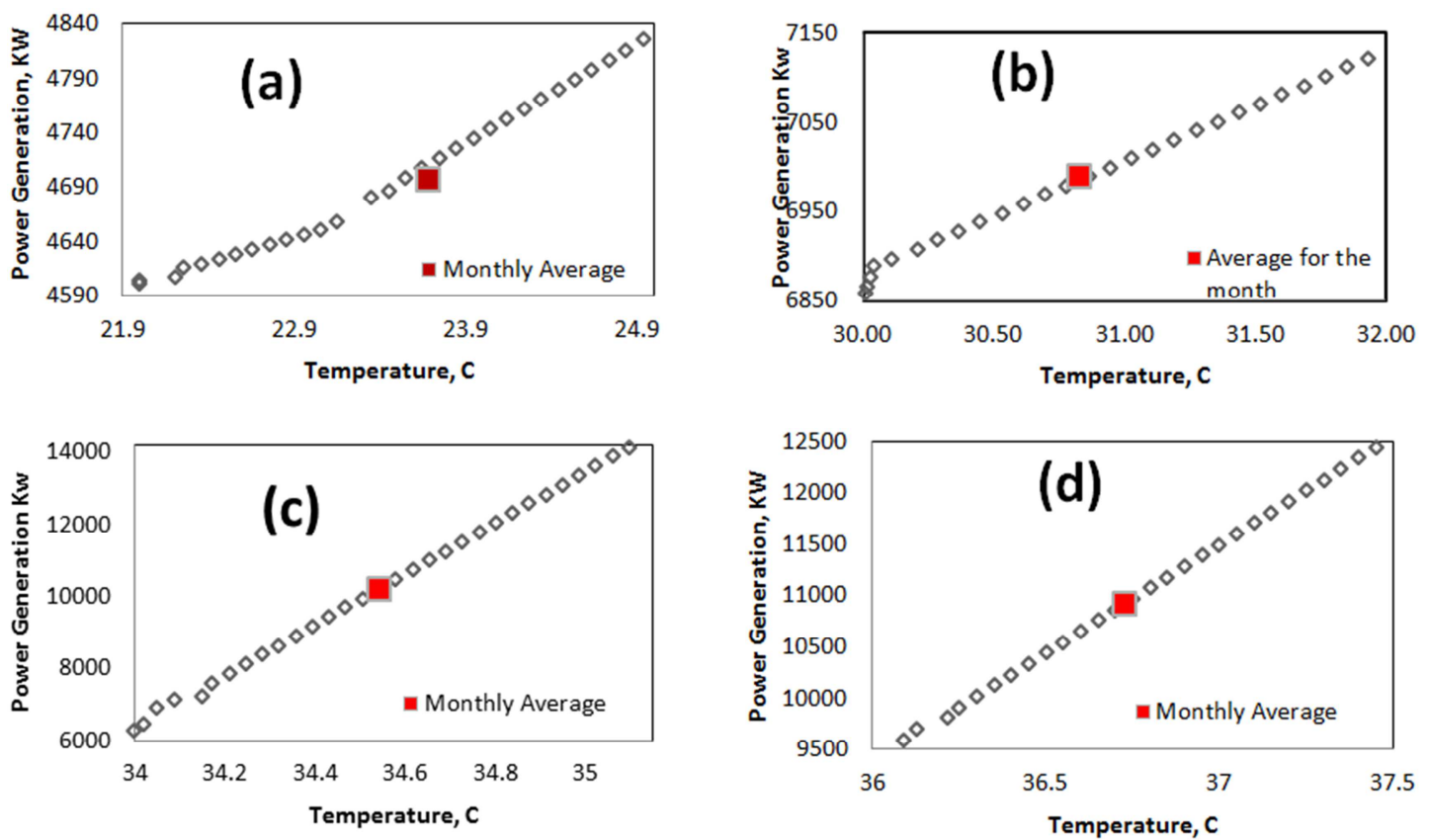

Fig. 3. Effect of temperature on power generation for (a) January, (b) February, (c) March and (d) April 2014.
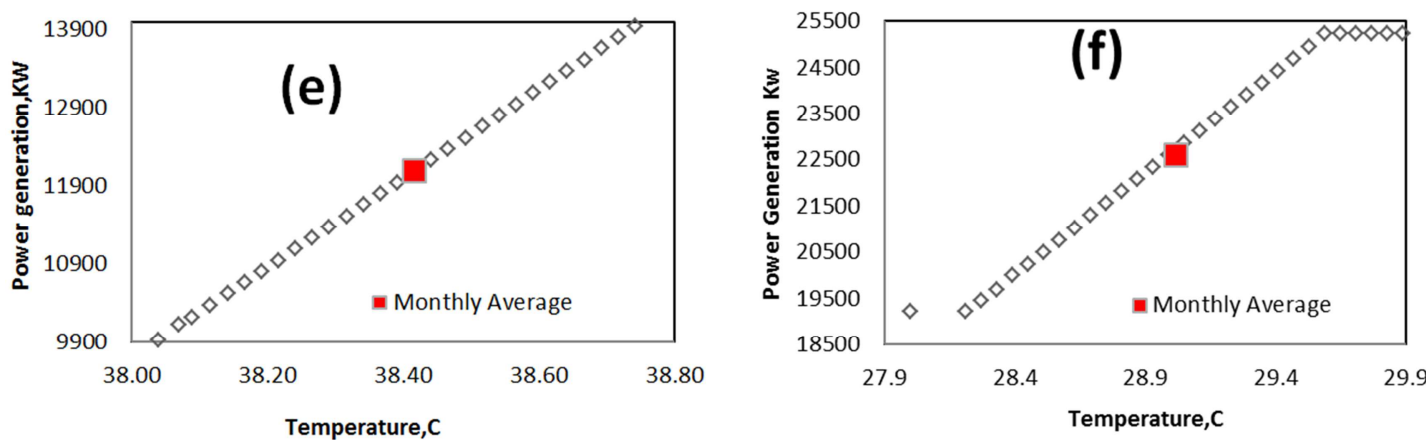

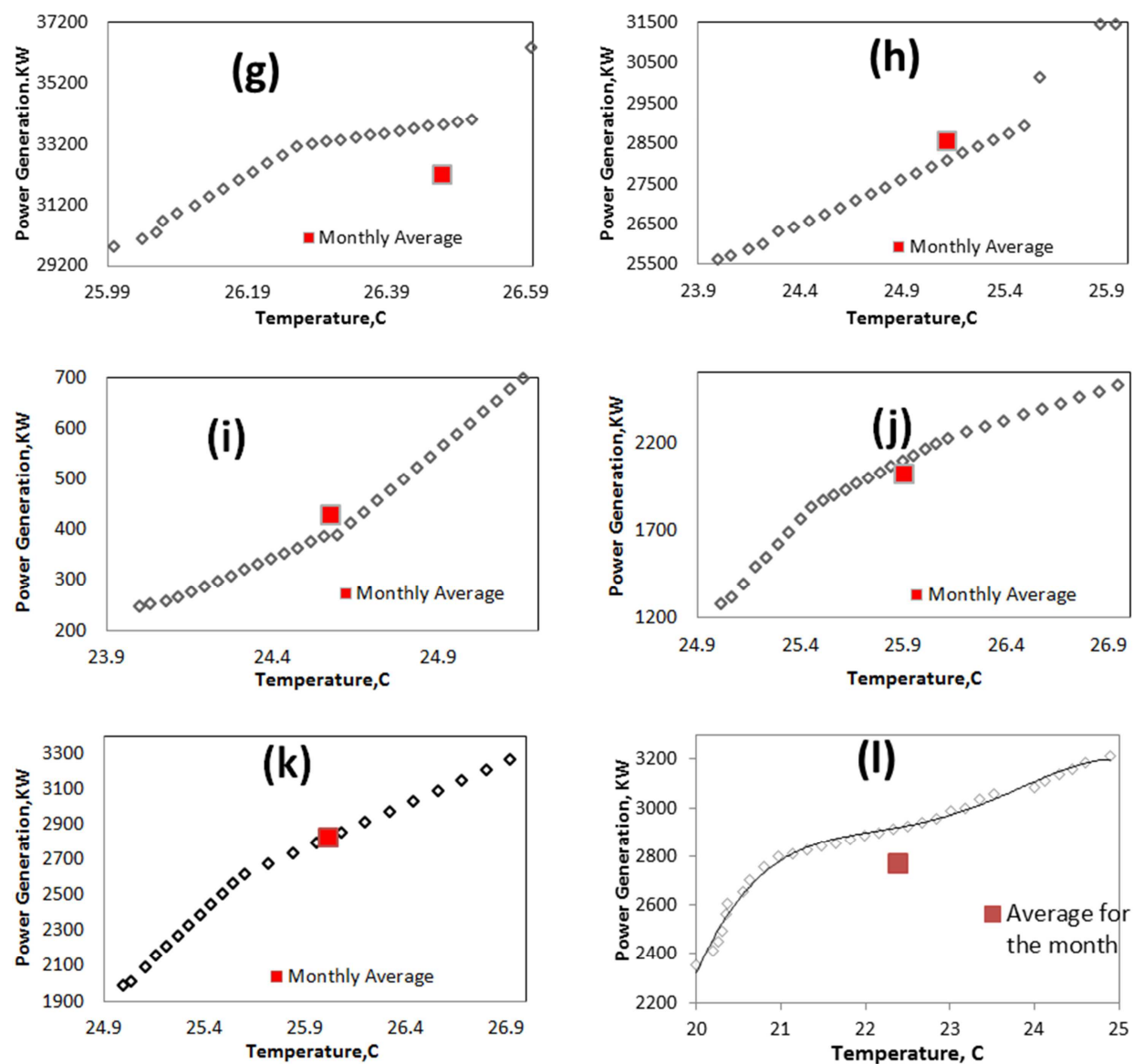

Fig. 4. Effect of temperature on power generation for (e) May, (f) June, (g) July, (h) August, (i) September, (j) October, (k) November and (l) December 2014.
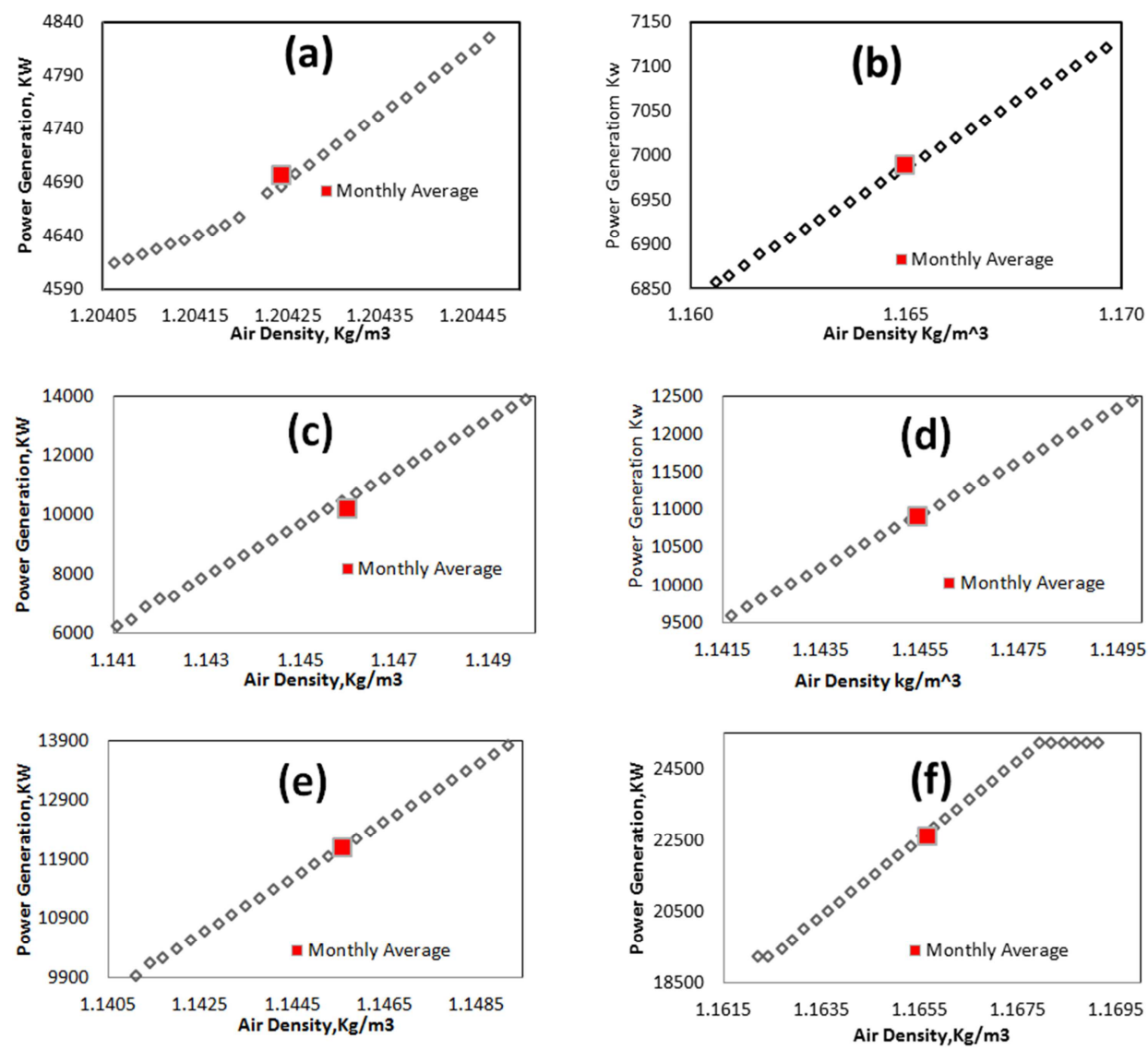

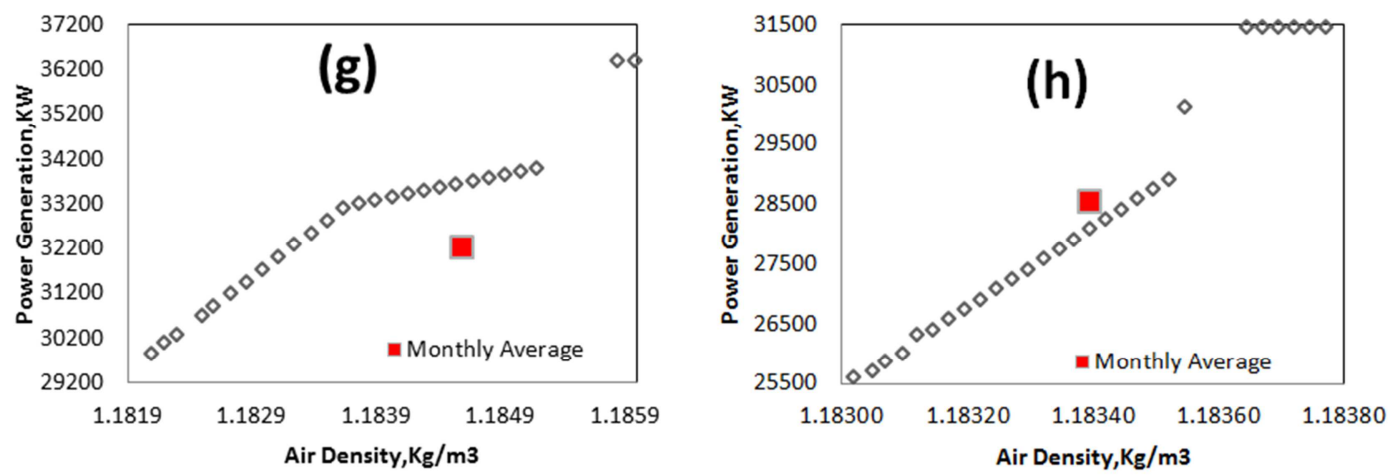

Fig. 5. Effect of air density on power generation for (a) January, (b) February, (c) March, (d) April, (e) May, (f) June, (g) July and (h) August 2014.
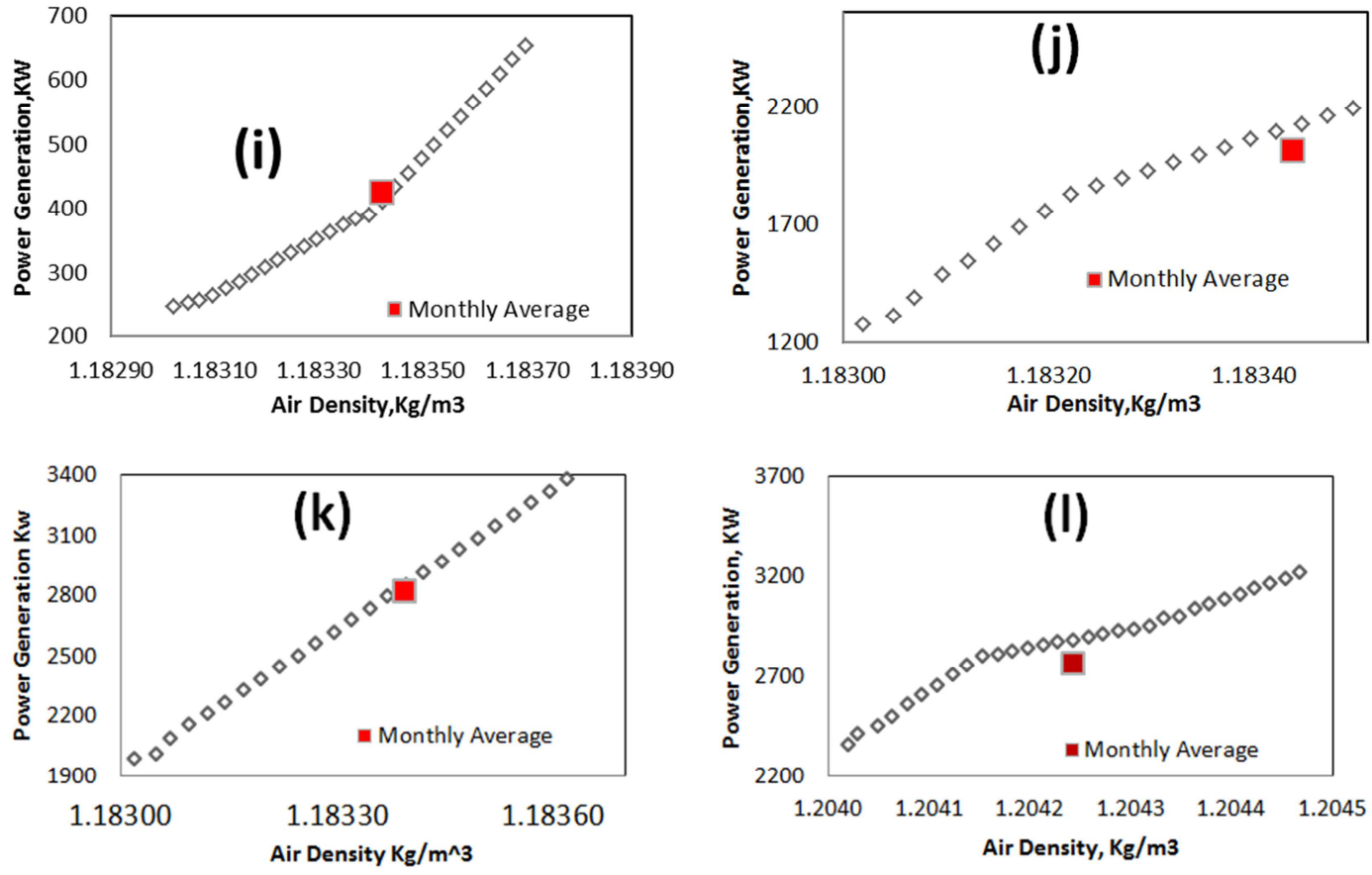

Fig. 6. Effect of air density on power generation for (i) September, (j) October, (k) November and (l) December 2014.

\section{WIND TURBINE ANALYSIS}

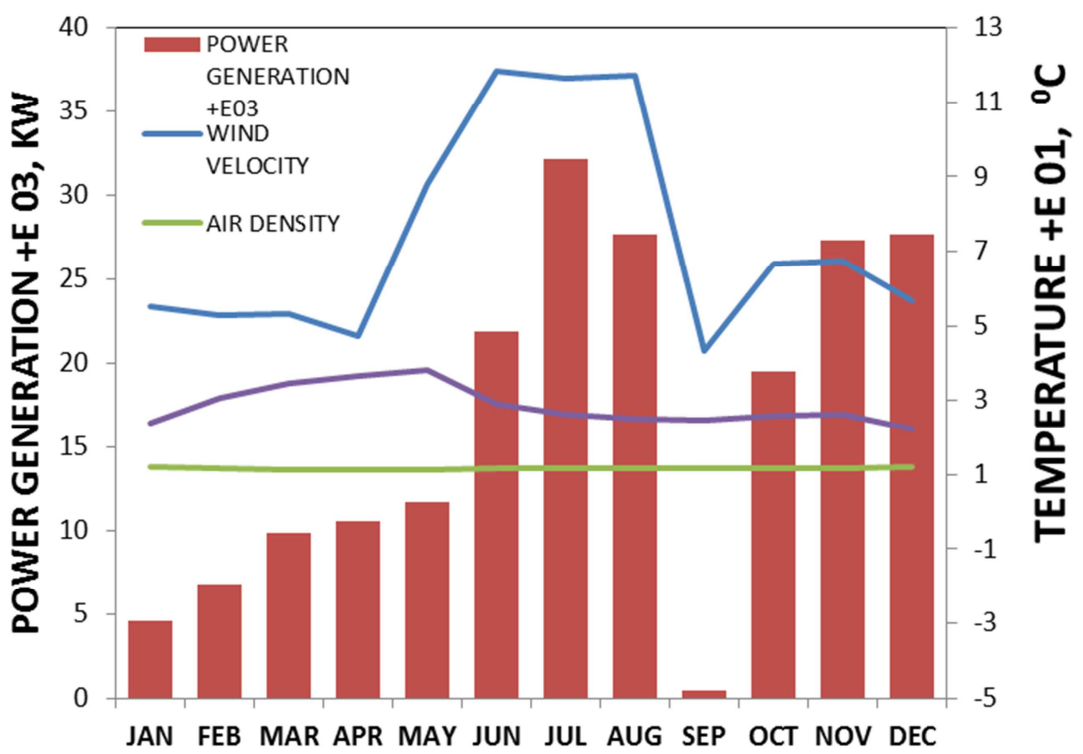

Fig. 7. Effect of wind speed, temperature and air density on power generation, combined effect. 


\section{Results and Discussion}

As shown by the figures above (fig. 1 to 7 ) the power generation for the entire year 2014 was monitored and special emphasis was given to understand and interpret the effect of various parameters on power generation. Three such factors have been identified it, namely wind speed $(\mathrm{m} / \mathrm{s})$, temperature of air $\left({ }^{\circ} \mathrm{C}\right)$ and density of air $\left(\mathrm{Kg} / \mathrm{m}^{3}\right)$. The natural variation of parameters has been recorded, plotted and analyzed for the entire year 2014. The following can be observed:

1. When the wind speeds are larger, large power generation is possible. This is evident especially in the months of June, July and August. Very low power generations have been observed in September and November where wind speeds are quite low. According to Betz's law, the power generation is proportional to $3^{\text {rd }}$ power of wind speed. Hence in comparison with any other parameter effect of wind speed will predominate the power generation.

2. It is observed further that air density is comparatively large in the month of June-August with the corresponding increase in power generation. Air density is also large in September-December. but the wind speed is low and hence the power generation values are low.

3. The effect of temperature on power generation was observed and it was seen that on dry days (nonmonsoon period) larger temperature causes more power generation. However since the variation of temperature throughout the year is only marginal $\left(20^{\circ} \mathrm{C}\right.$ to $\left.39^{\circ} \mathrm{C}\right)$ no profound effect is noted. In countries where winters are sever, temperature might be a very important parameter. It is also seen that in tropical countries like India, in part of western mountainous region of Maharashtra, which is hotter than cold throughout the year, the effect of temperature is not seen much.

4. The Betz's equation $P=1 / 2 \rho A V^{3} \mathrm{Cp}$ watts indicates that wind velocity will have most profound effect on power generation, since the velocity has power of three $\left(\mathrm{V}^{3}\right)$. This has also reflected in this work to be true

\section{Conclusion}

The result of a variety of parameters on the power generation in the mountainous regions in Maharashtra, India was scrutinized and calculated for the entire year 2014 . Analysis of this result was done with the aid of power curves in which the most profound effect of wind speed on power generation for the duration of this entire period was examined and noted. On the other hand, at the end of the findings and this study and we come to a conclusion that we have to also consider the fact that these findings are and will be difficult to generalize for wind power generation; because as we all are aware a lot of a times it may demonstrate a discrepancy with local parameters.

\section{References}

[1] Demirbas A. Biomass and the other renewable and sustainable energy options for Turkey in the twenty-first century. Energy Sources, V. 23 pp. 177-87, (2001).

[2] Cavallo A. J, Grubb M. J. Renewable energy sources for fuels and electricity. London: Earthscan Publications Ltd, (1993).

[3] Celik A. N. A simplified model for estimating the monthly performance of autonomous wind energy systems with battery storage. Renewable Energy, V. 28, pp. 561-72, (2003).

[4] Ravindra B Sholapurkar and Yogesh S Mahajan, Review of wind energy development and policy in India, Energy Technology and Policy, V. 2, pp. 122-132, (2015).

[5] Renewable Energy Resources: Opportunities and Constraints 1990 - 2020, study performed and published by the World Energy Council, London, UK, (1993).

[6] Lazar Lazic, Goran Pejanovic, Momcilo Zivkovic and Luca Llic, Improved wind forecasts for wind power generation using the Eta model and MOS (Model Output Statistics) method, Energy, pp. 567-574, (2014).

[7] Akpinar E. K, Akpinar S, An assessment on seasonal analysis of wind energy characteristics and wind turbine characteristics, Energy Conservation and Management, V. 46, pp. 1848-67, (2004).

[8] Lun I. Y. F., J. C. Lam, A study of Weibull parameters using long-term wind observations, Renewable Energy V.20, pp. 145-153, (2000).

[9] Seguro J. V., T. W. Lambert, Modern estimation of the parameters of the Weibull wind speed distribution for wind energy analysis, Journal of Wind Engineering and Industrial Aerodynamics, V.85 pp.75-84, (2000).

[10] Pechak Olena, Mavrotas George, Diakoulaki Danae., Role and contribution of the clean development mechanisms to the development of wind energy, Energy, V.7, pp.75-85, (2011).

[11] Ali Naci Celik, Energy output estimation for small-scale wind power generators using weibull-representative data, Journal of Wind Engineering and Industrial Aerodynamics, V. 91, pp. 693-707, (2003).

[12] Gipe P., Wind Energy Comes of Age, Wiley, New York, NY, (1995).

[13] Olayinka S. Ohunakin, Olaolu O. Akinnawonu., Assessment of wind energy potential and the economics of power generation in Jos Plateau state, Nigeria, Sustainable for Energy, V.16, pp.78-83. (2012).

[14] Tow Leong Tiang, Dahaman Ishak., Technical review of wind energy potential as small-scale power generation sources in Penang Island Malasia, Renewable and sustainable energy review. V. 16, pp. 3034-3042, (2012).

[15] Casale C., E. Sesto, Wind Power Systems for Power Utility Grid Connection, Advances in Solar Energy, V. 9, USA, (1994). 
[16] Sesto E., D. F. Ancona, Present and prospective role of wind energy in electricity supply, in: Proc. Of New Electricity 21, Paris, OECD Publications, Paris, France, (1995).

[17] Marco Rauge, Ilvia Bargigli, Sergio Ulgiati, Life cycle assessment and energy payback time of advanced photovoltaic modules: Cd Te and CIS compared to poly-Si, Energy, V. 32, pp. 1310-1318, (2007).

[18] Keith M Sundeland, Gerald Mills, Michael F Conlon, Estimating the wind resource in an urban area: A case study of micro-wind generation potential in Dubin, Ireland, Journal of Wind Engineering and Industrial Aerodynamics., V. 118, pp. 44-53, (2013).

[19] Landberg L., Short-term prediction of the power production from wind farms, Journal of Wind Engineering and Industrial Aerodynamics. V. 80, pp. 207-220, (1999).

[20] https://nccr.iitm.ac.in/ebook\%20final.pdf B. Viswanathan., An introduction to energy sources, national center for catalysis research department of chemistry Indian institute of technology, Madras, (2006).

[21] Sfetsos A., A comparison of various forecasting techniques applied to mean hourly wind speed time- series, Renewable Energy. V. 21, pp. 23-35, (2000).
[22] http://onlinelibrary.wiley.com/doi/10.1002/9783527646289.ch 1/summary, Edward L. Wolf, A Survey of Long-Term Energy Resources, Nanophysics of Solar and Renewable Energy, Wiley publication, (2012).

[23] Thor S, Taylor P W., Long-term research and development needs for wind energy for the time frame 2000-2020. Wind Energy. V. 5, pp. 73-75, (2002).

[24] Trivedi M P, 1999. Environmental factors affecting wind energy generation in western Coastal region of India. Renewable Energy, V. 16, pp. 894-898, (1999).

[25] Zhigang Lu, Shoulong He, Tao Feng, Xueping Li, Xiaoqiang Guo and Xiaofeng Sun, Robust economic/emission dispatch considering wind power uncertainties and flexible operation of carbon capture and storage, International Journal of Electrical power and Energy Systems, V. 63, pp. 285-292, (2014).

[26] Rai G. D. Non-Conventional Energy sources, Khanna Publishers, (2011).

[27] Masseran, A M, Razali K Ibrahim, An analysis of wind power density derived from several wind speed density functions: the regional assessment on wind power in Malaysia, Renewable and Sustainable Energy Reviews, V. 16, pp. 6476-6487, (2012). 